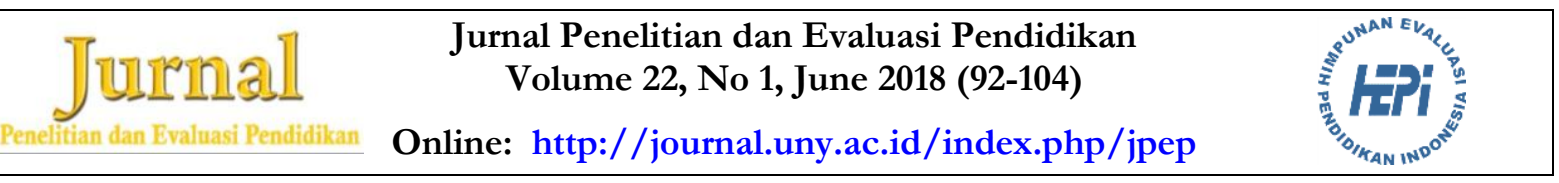

\title{
PENGEMBANGAN INSTRUMEN ASESMEN DIRI GURU TERHADAP AKTIVITAS PENGEMBANGAN KEPROFESIAN BERKELANJUTAN
}

\author{
Wirman Kasmayadi ${ }^{1}{ }^{*}$, Kumaidi ${ }^{2}$, Sumarno ${ }^{3}$ \\ ${ }^{1}$ LPMP Prov. Tenggara Barat, ${ }^{2}$ Univ. Muhammadiyah Surakarta, ${ }^{3}$ Univ. Negeri Yogyakarta \\ ${ }^{1}$ Jl. Panji Tilar Negara No.8, Taman Sari, Ampenan, Mataram, NTB 83114, Indonesia \\ ${ }^{2} J 1$. A. Yani, Mendungan, Pabelan, Kartasura, Kab. Sukoharjo, Jawa Tengah 57162, Indonesia \\ ${ }^{3} J 1$. Colombo No. 1, Depok, Sleman 55281, Yogyakarta, Indonesia \\ * Corresponding Author. Email: wirkasmayadi@yahoo.com
}

\begin{abstract}
Abstrak
Penelitian ini bertujuan untuk mengembangkan instrumen asesmen diri guru pada aktivitas pengembangan keprofesian berkelanjutan yang handal. Metode penelitian yang digunakan adalah penelitian pengembangan yang mengacu pada lima tahapan dalam model Plomp. Subyek penelitian adalah guru SMA di Provinsi Nusa Tenggara Barat yang dipilih dengan teknik cluster random sampling. Jumlah subyek penelitian pada uji coba awal sebanyak 350 orang dan uji coba lapangan utama sebanyak 950 orang. Pengumpulan data menggunakan kuesioner skala Likers (1-5). Pengujian validitas isi menggunakan expert judgment, sedangkan validitas dan reliabilitas empiris menggunakan analisis faktor konfirmatori (CFA) dengan bantuan program Lisrel 8.80. Hasil penelitian menunjukkan bahwa: (1) konstrak aktivitas pengembangan keprofesian berkelanjutan guru memiliki tujuh dimensi, yaitu: membaca, pengembangan pembelajaran dan penilaian, pendidikan dan pelatihan, publikasi ilmiah, publikasi karya inovatif, reflektif dan kolaboratif; (2) instrumen yang telah dikembangkan secara keseluruhan memiliki kecocokan sebagai model asesmen yang baik dengan RMSEA 0.005 dan CFI 1.00 (valid) dan composite reliability lebih dari 0.70 (reliable).
\end{abstract}

Kata kunci: asesmen diri guru, pengembangan keprofesian berkelanjutan

\section{DEVELOPING TEACHERS' SELF-ASSESSMENT INSTRUMENT FOR SUSTAINABLE PROFESSIONAL DEVELOPMENT ACTIVITIES}

\begin{abstract}
This research is aimed at developing a reliable teachers' self-assessment instrument for sustainable professional development activity. This study was a development research using five-stage model of Research and Development by Plomp. The subjects are high school teachers in the West Nusa Tenggara province, that were selected by cluster random sampling technique. The research subjects in preliminary field test were 350 people and in the main field test were 950 people. The data were collected using Likers scale (1-5) questionnaire. The content validity was tested using expert judgment, whereas the empirical validity and reliability were tested using confirmatory factor analysis (CFA) with Lisrel 8.80 program. The results of the research show that: (1) the construct of teachers' sustainable professional development activities has seven dimensions, namely: reading, learning and assessment development, education and training, scientific publications, the publication of innovative works, reflective and collaborative; (2) the instruments have an overall fit as a good assessment model with the value of RMSEA 0.005, CFI 1.00 (Valid), and composite reliability of more than 0.70 (reliable).
\end{abstract}

Keywords: teachers' self-assessment, sustainable professional development

Permalink/DOI: bttp://dx.doi.org/10.21831/pep.v22i1.8290

Jurnal Penelitian dan Evaluasi Pendidikan

ISSN 1410-4725 (print) ISSN 2338-6061 (online) 


\section{Pendahuluan}

Penyelenggaraan pendidikan yang berkualitas membutuhkan guru profesional. Predikat profesional dapat terwujud apabila guru dapat mengembangkan keprofesiannya secara berkelanjutan. Tuntutan terhadap pengembangan keprofesian berkelanjutan semakin tinggi seiring dengan hadirnya dinamika perubahan saat ini, dimana guru dihadapkan pada perubahan yang cepat, permintaan standar yang tinggi, dan tuntutan peningkatan mutu pendidikan.

Pengembangan keprofesian menjadi lebih diperlukan oleh guru sebagai fasilitator kegiatan pembelajaran di sekolah. Guru dan fasilitator memiliki tanggungjawab untuk membelajarkan peserta didik agar mampu menghadapi dinamika perubahan yang sedang dan akan terjadi, baik perubahan teknologi, ilmu pengetahuan, maupun struktur ketenagakerjaan. Pada kondisi demikian, guru harus memiliki inisiatif sendiri dan termotivasi secara intrinsik untuk selalu mengupdate, meningkatkan dan memperluas kompetensinya melalui pengembangan keprofesian secara berkelanjutan.

Perlunya pengembangan keprofesian berkelanjutan bagi guru didukung oleh beberapa hasil studi. Berdasarkan hasil uji kompetensi guru (UKG), bahwa kompetensi profesional dan pedagogis guru di Indonesia masih rendah, dimana nilai rata-rata nasional UKG 2012 sebesar 44,5(Zubaidah, 2012) serta UKG 2015 dengan nilai 53,02 (Wurinanda, 2015). Kondisi guru tersebut berimplikasi pada rendahnya pencapaian prestasi peserta didik Indonesia pada tes standar internasional tahun 2011 (TIMMS, PISA, PIRLS) yang menunjukkan bahwa peringkat peserta didik Indonesia berada pada posisi kelompok bawah (Mullis, Martin, Foy, \& Arora, 2012, p. 42).

Istilah yang berkaitan dengan pengembangan keprofesian berkelanjutan diantaranya adalah continuing professional development. Menurut Kelchtermans (2004, p. 220) bahwa pengembangan keprofesian berkelanjutan merupakan proses pembelajaran dari interaksi dengan lingkungan sosial, sekolah dan budaya, sehingga menimbulkan perubahan dalam praktik (tindakan) profesional dan pemikiran guru tentang praktiknya. Dengan demikian, pengembangan keprofesian berkelanjutan menunjukkan proses belajar guru dan hasil belajar ini akan terlihat tidak hanya dalam perubahan praktik profesional seseorang (misalnya, performa yang lebih efektif), tetapi juga dalam berpikir tentang bagaimana dan mengapa praktik itu.

Day \& Sachs (2004, p. 219) mengungkapkan bahwa pengembangan keprofesian berkelanjutan sebagai upaya pengembangan yang terdiri dari seluruh pengalaman belajar yang dialami dan aktivitas-aktivitas sadar yang direncanakan dan dimaksudkan secara langsung maupun tidak langsung untuk memberi manfaat pada individu, kelompok, sekolah, serta berkontribusi pada kualitas pendidikan di ruang kelas. Dengan demikian, pengembangan keprofesian mencakup segala aktivitas yang memenuhi baik kebutuhan individual guru maupun kebutuhan institusional sekolah. Guru, sekolah, dan peserta didik mendapatkan manfaat dari proses pengembangan keprofesian tersebut.

Definisi ini menyoroti fungsi dan peran pengembangan keprofesian berkelanjutan secara terpisah, namun saling terkait antara aspek fungsi, hubungan antara individu dan kolegialitas dalam kegiatan pengembangan. Pertama, pengembangan keprofesian berkelanjutan guru secara personal dapat saja memiliki fungsi yang berbeda, namun tetap berorientasi pada pemeliharaan, peningkatan, atau perluasan kompetensi. Guru harus belajar secara berkelanjutan agar dapat memperbarui pengetahuan dan keterampilannya dengan belajar strategi, teknik, dan metode baru untuk memenuhi tantangan kelas baru, memperbaiki diri dan mengubah sekolah menjadi masyarakat belajar, serta dapat merespon perubahan pendidikan.

Kedua, fungsi pengembangan keprofesian berkelanjutan menekankan adanya hubungan simbiosis yang saling menguntungkan antara kebutuhan individu dan organisasi. Dalam komunitas belajar profesional, guru terfokus pada belajar peserta 
didik, berbagi nilai dan visi, tanggung jawab kolektif, inkuiri, profesional reflektif, kolaborasi, serta belajar kelompok dan individu. Berpartisipasi dalam kegiatan profesional yang variatif berarti guru telah menstimulus dirinya sebagai pembelajar mandiri dan pengembangan sekolah, sehingga guru memberikan kontribusi yang signifikan untuk meningkatkan praktik pendidikan.

Gaible \& Burns (2005, pp. 15-16) mengklasifikasikan model pengembangan keprofesian guru menjadi tiga kelompok besar, yaitu standar/formal; mandiri/informal; dan berbasis tempat. Pertama, pengembangan keprofesian guru standar/formal yang didefinisikan oleh de Vries, Jansen, \& van de Grift (2013, p. 870) sebagai kesempatan belajar formal dengan lingkungan belajar terstruktur dengan kurikulum tertentu, penyelenggaraan secara formal dan difasilitasi oleh lembaga atau organisasi pemerintah atapun lembaga swadaya masyarakat sebagai penyelenggara kegiatan belajar.

Dalam implementasinya, aktivitas pengembangan keprofesian guru standar diselenggarakan dalam bentuk program kualifikasi guru melalui pendidikan gelar atau non gelar. Selain itu, aktivitas belajar formal lainnya, seperti kursus, workshop, pelatihan, membaca buku siswa, pedoman guru serta jurnal profesional dalam upaya menyegarkan dan memperbaharui pengetahuan dan keterampilan dengan konten terbaru, terkait dengan materi pelajaran, metode/strategi pembelajaran, pengembangan kurikulum, dan kegiatan sejenis lainnya.

Kedua, pengembangan keprofesian guru mandiri atau informal. Menurut Desimone (2009, p. 287), pengembangan keprofesian informal tidak mengikuti kurikulum yang ditentukan dan tidak terbatas pada lingkungan tertentu. Aktivitas belajar meliputi kegiatan individu seperti membaca buku dan observasi kelas serta kegiatan kolaboratif seperti diskusi dengan kolega dan orang tua, mentoring, jaringan guru dan kelompok penelitian. Partisipasi dalam kegiatan belajar informal, umumnya tidak wajib, tetapi atas inisiatif guru sendiri. Oleh karena itu, guru tidak hanya sebagai pe- nerima pengetahuan, tetapi sebagai pembelajar mandiri dengan mengatur proses belajar dan menentukan tujuan belajar serta strategi secara mandiri.

Selain itu, kesempatan belajar informal sering tertanam dalam kelas atau konteks sekolah, yang memungkinkan para guru untuk merefleksikan praktik dan belajar dari koleganya (Borko, 2004, p. 256). Dengan demikian, dapat dijelaskan bahwa pengembangan keprofesian informal atau mandiri sangat cocok bagi guru dengan alasan, yaitu: (1) karakteristik guru sebagai pembelajar orang dewasa (adult learner), (2) kesempatan belajar yang lebih besar, ditinjau dari perspektif rencana, inisiatif, proses dan strategi/metode, serta pelaksanaannya yang dikendalikan sendiri oleh pembelajar, dan (3) pilihan kegiatan sangat variatif sesuai dengan kebutuhan guru dan tidak terbatas pada pilihan aktivitas yang secara langsung terkait dengan kebutuhan kelas maupun kinerja profesinya.

Ketiga, pengembangan keprofesian guru berbasis-tempat. Day \& Sachs (2004, p. 13) membedakan pengembangan keprofesian guru meliputi, (1) belajar di sekolah seperti melalui: coaching teman sejawat, mentoring, critical friendship, active research, team planning and assessment, appraisal; (2) belajar di luar sekolah seperti melalui: school-led renewal or reform networks, school-university partnership, subject or phone-specific network, professional development centres.

Sehubungan dengan guru sebagai pembelajar mandiri (autonomous learner), Benson (2007, p. 345) berpendapat bahwa pembelajar yang mandiri merupakan pembelajar yang mampu mengambil tanggung jawab untuk menentukan tujuan, konten, dan metode pembelajaran mereka sendiri, serta mampu memonitor kemajuannya dan mengevaluasi luaran yang dihasilkan. Dengan demikian, para guru seharusnya berperilaku sebagai pembelajar mandiiri dalam pengembangan keprofesian.

Terkait dengan konteks bekerja (sekolah) sebagai setting pelaksanaan aktivitas pengembangan keprofesian guru, ditemukan beberapa hasil penelitian. Pertama, Kwakman 
(2003, pp. 159-160) melakukan studi literatur terhadap aktivitas belajar keprofesian guru, hasilnya membedakan empat kategori aktivitas belajar guru, yaitu: (1) membaca, (2) bereksperimen, (3) refleksi, dan (4) kolaborasi.

Kedua, Hoekstra, Brekelmans, Beijaard, \& Korthagen (2009, pp. 664-665) mengungkapkan empat kategori utama dari kegiatan belajara guru di tempat kerja, yaitu: (1) belajar dengan bereksperimen, (2) belajar dengan mempertimbangkan praktik mengajar sendiri, (3) belajar dengan mendapatkan gagasan dari kolega, dan (4) belajar sambil bekerja.

Ketiga, Bakkenes, Vermunt, \& Wubbels (2010, pp. 539-540) telah melakukan analisis konten terhadap pengalaman belajar guru dan hasilnya diklasifikan menjadi enam kategori, yaitu (1) eksperimen (mencoba sesuatu yang baru dalam praktik pembelajaran); (2) mempertimbangkan praktik sendiri (refleksi terhadap praktik pembelajaran dan hasil belajar peserta didik; (3) mendapatkan ide dari orang lain; (4) memperhatikan kesenjangan antara harapan dengan realitas di kelas; (5) beusaha untuk mengubah pengajaran agar tidak kembali ke rutinitas lama; dan (6) terlibat dalam aktivitas pengembangan agar agar terus belajar tentang metode/strategi baru.

Keempat, Tynjälä (2008, p. 135) telah melakukan studi literatur dan melakukan kajian bagaimana individu belajar di tempat kerja, yaitu: (1) melakukan pekerjaan sendiri; (2) berinteraksi dengan kolega; (3) bekerja dengan pelanggan; (4) mengerjakan tugas yang menantang dan tugas baru; (5) melakukan refleksi dan evaluasi pengalaman kerja; (6) pendidikan formal; dan (7) melakukan kerja ekstra.

Kelima, pelaksanaan pengembangan keprofesian berkelanjutan guru di Indonesia mengacu pada Pedoman Pengelolaan Pengembangan Keprofesian Berkelanjutan (PKB) Guru (Menteri Pendidikan dan Kebudayaan Republik Indonesia, 2010, p. 18) dengan aktivitas guru meliputi: (1) kegiatan mandiri di sekolah, (2) kegiatan di sekolah dengan berkolaborasi bersama guru lain, (3) kegiatan melalui jaringan sekolah, dan (4) kegiatan yang difasilitasi oleh kelompok kepakaran lain, seperti dosen, widyaiswara, dan guru inti.

Berdasarkan hasil kajian literatur dan mengacu pada aktivitas pengembangan keprofesian berkelanjutan guru di Indonesia, maka dimensi aktivitas pengembangan keprofesian berkelanjutan guru pada penelitian ini, adalah: (1) membaca, (2) pengembangan pembelajaran dan penilaian, (3) pendidikan dan pelatihan, (4) publikasi ilmiah, (5) publikasi karya inovatif, (6) refleksi, dan (7) kolaborasi.

Hasil kajian menunjukkan bahwa asesmen diri merupakan cara ampuh untuk mengembangkan otonomi dalam belajar. Namun pada kenyataannya, kajian sistematis mengenai hal ini belum banyak dilakukan oleh peneliti pendidikan. Demikian pula pengamatan di lapangan menunjukkan bahwa para pendidik belum secara sadar mengimplementasikan asesmen diri dalam pengembangan keprofesian berkelanjutan.

Asesmen diri merupakan pelibatan pembelajar dalam menentukan standar dan/ atau kriteria keberhasilan untuk menilai hasil belajarnya sendiri, sehingga dapat menentukan sejauhmana keberhasilan telah tercapai berdasarkan standar atau kriteria (Brew, 1999, p. 568). Dengan demikian, terdapat dua unsur pada setiap proses asesmen, yaitu penentuan standar terkait dengan kriteria tertentu, dan penilaian terhadap karya berdasarkan standar dan kriteria. Melalui asesmen diri, pembelajar dapat melihat, bukan hanya kekurangannya, tetapi juga kelebihan yang dimilikinya, untuk selanjutnya kekurangan ini akan menjadi tujuan perbaikan, sedangkan kelebihannya akan menjadi motivasi untuk selalu berkembang.

Sehubungan konsep asesmen diri, Rolheiser \& Ross $(2005$, p. 254) telah mengajukan suatu model teoretik untuk menunjukkan kontribusi asesmen diri pada pencapaian tujuan belajar. Model ini menekankan pada proses evaluasi diri. Saat mengevaluasi diri sendiri, pembelajar terdorong untuk menetapkan tujuan yang lebih tinggi (goals) dan berusaha lebih keras (effort). 
Kombinasi tujuan goals dan effort ini menentukan prestasi (achievement). Selanjutnya prestasi ini berakibat pada penilaian diri (selfjudgment) melalui kontemplasi seperti pertanyaan, "apakah tujuanku telah tercapai"? akibatnya timbul reaksi (self-reaction), seperti "apa yang dirasakan dari prestasinya?". Dengan demikian, maka goals, effort, achievement, self-judgment, dan self-reaction dapat terpadu untuk membentuk kepercayaan diri (selfconfidence) yang positif. Selanjutnya, kedua penulis juga menekankan bahwa asesmen diri adalah kombinasi dari komponen selfjudgment dan self-reaction dalam model di atas.

Selain itu. kedua penulis di atas meyakini bahwa asesmen diri dapat meningkatkan hasil belajar, karena beberapa alasan, yaitu: (a) dapat memusatkan perhatian pebelajar pada tujuan pembelajaran, (b) memberikan informasi pada guru mengenai halhal yang masih kurang atau belum tercapai dalam pembelajaran, (c) dapat lebih meningkatkan perhatian pebelajar pada asesmen, dan (d) meningkatkan motivasi pebelajar.

Melalui asesmen diri, pembelajar akan dapat menentukan tujuan belajarnya dan berusaha keras untuk mencapai tujuan itu. Oleh karena itu, asesmen diri secara langsung dapat meningkatkan proses dan hasil belajar, sehingga mereka mampu mengarahkan dirinya untuk belajar secara mandiri.

Terkait dengan kegiatan pengukuran aktivitas pengembangan keprofesian berkelanjutan, diperlukan suatu instrumen untuk melaksanakan asesmen diri guru terhadap aktivitas pengembangan keprofesian berkelanjutan yang telah teruji, baik validitas maupun reliabialitasnya. Dalam kegiatan penelitian khususnya dalam bidang pendidikan, terdapat dua bentuk instrumen yang dapat digunakan yakni tes dan non-tes. Instrumen yang berbentuk tes biasanya untuk mengukur prestasi, seperti prestasi belajar.

Sementara itu, instrumen non-tes pada umumnya digunakan untuk mengukur sikap. Dalam penelitian pendidikan, salah satu instrumen non-tes yang sering digunakan adalah kuisioner (angket). Secara umum, ada dua jenis kuisioner yaitu kuisioner ter- tutup dan terbuka. Kuisioner tertutup adalah kuisioner yang telah disediakan alternatif jawabannya sehingga responden tinggal memilih yang sesuai dengan keadaan dirinya. Sedangkan kuisioner terbuka adalah kuisioner yang jawabannya belum disediakan sehingga responden bebas menuliskan apa yang dirasakan. Satu hal yang menjadi ciri utama suatu kuisioner adalah tidak ada jawaban benar atau salah.

Ketersediaan instrumen aktivitas pengembangan keprofesian berkelanjutan guru sangat diperlukan, mengingat perkembangan terkini menunjukkan penelitian tentang pengembangan keprofesian guru sedang berkembang, baik di lingkungan perguruan tinggi maupun sekolah. Oleh karena itu, penelitian ini berfokus pada pengembangan instrumen asesmen diri terhadap aktivitas pengembangan keprofesian guru secara berkelanjutan. Pengembangan instrumen asesmen diri terhadap aktivitas pengembangan keprofesian berkelanjutan guru sangat penting dalam konteks pengembangan mutu pendidikan. Dengan demikian, penelitian ini diharapkan dapat menghasilkan instrumen asesmen diri terhadap aktivitas pengembangan keprofesian berkelanjutan guru memenuhi validitas dan reliabilitas yang baik. Hasil ini penting untuk ikut membantu meningkatkan ketersediaan intrumen baku yang dibutuhkan para peneliti.

\section{Metode Penelitian}

Penelitian ini merupakan penelitian dan pengembangan (Research and Development) dengan memadukan model Borg \& Gall (1983, p. 775) dengan model pengembangan Plomp. Sepuluh langkah dari model Borg \& Gall dimodifikasi menjadi lima tahap (stage) seperti tahapan dalam model Plomp (2007, p. 15). Langkah-langkah tersebut adalah: (1) melakukan studi pendahuluan untuk menganalisis produk yang akan dikembangkan, (2) mengembangkan design (3) mengembangkan produk dan validasi produk, (4) melakukan uji coba lapangan, (5) diseminasi/implementasi.

Penelitian dilaksanakan pada bulan Februari sampai April 2015 di provinsi 
Nusa Tenggara Barat. Penentuan sampel penelitian dilakukan dengan teknik purposive random sampling. Daerah sampel yang dipilih mewakili karakteristik wilayah kota dan kabupaten, yaitu Kota Mataram, Kabupaten Lombok Barat, Kabupaten Lombok Tengah dan Kabupaten Lombok Timur. Distribusi sampel sekolah dalam studi mencerminkan lokasi sekolah, yaitu di ibukota provinsi (SMA di kota Mataram), ibukota kabupaten (SMA di ibukota kabupaten Lombok Barat, Lombok Tengah dan Lombok Timur), dan ibukota kecamatan (SMA di kecamatan dalam kabupaten). Penentuan sampel responden guru (sumber data) sebagai subjek uji, ditetapkan semua guru mata pelajaran di SMA yang terpilih.

Pada tahap uji coba awal dilakukan survei pada sampel kecil, yaitu pada 10 (sepuluh) SMA negeri yang mencerminkan kategori sekolah dengan kualitas baik, sedang dan kurang di wilayah kota/kabupaten berdasarkan rerata nilai ujian nasional. Dalam hal ini, sampel responden pada uji coba tahap awal sebanyak 350 guru. Sementara itu, uji coba tahap akhir dilakukan pada skala yang lebih luas, yaitu pada 60 SMA negeri dan swasta dengan karakteristik yang sama dengan tahap uji coba awal. Dengan demikian, maka jumlah responden sebagai subjek uji pada uji coba tahap akhir adalah sebanyak 950 guru.

Variabel operasional dalam penelitian ini adalah aktivitas pengembangan keprofesian berkelanjutan guru. Adapun spesifikasi isi instrumen dalam penelitian ini dilakukan dengan menjabarkan terlebih dahulu konsep-konsep tentang pengembangan keprofesian berkelanjutan guru menjadi dimensi dan indikator yang mengungkap aktivitas pengembangan keprofesian berkelanjutan guru. Masing-masing indikator dibuat minimal dalam lima butir pernyataan. Jenis respons dalam penelitian ini adalah kinerja tipikal yang tidak dapat dinyatakan benar atau salah, tetapi dapat dikatakan semua respons benar menurut kondisi setiap responden. Sesuai dengan karakteristik jenis respon, maka format alat ukur yang dipilih untuk menyajikan butir-butir instrumen adalah fomat pilihan terbatas. Untuk tiap-tiap butir memiliki 5 pilihan jawaban yakni Tidak Pernah (TP), Jarang (JR), Kadang-kadang $(\mathrm{KK})$, Sering (SR), dan Selalu (SL). Penskoran dilakukan dengan memberikan skor 1=tidak pernah,$\quad 2=$ jarang, $3=$ kadangkadang, $4=$ sering, dan $5=$ selalu.

Analisis validitas konstrak aktivitas pengembangan keprofesian berkelanjutan guru dengan Confirmatory Factor analysis (CFA) dan metode estimasi ML (Maximum Likelihood. Sebelum dilakukan analisis Second Order CFA, terlebih dahulu dilakukan analisis faktor dengan SPSS 17.0 untuk memastikan terpenuhinya syarat analisis faktor, yaitu kecukupan jumlah data observasi dan adanya korelasi yang signifikan antara variabel-variabel observasi.

Menurut (Hair, Anderson, Tatham, \& Black (2010, p. 117), bahwa kecukupan jumlah observasi (data) dapat diidentifikasi melalui parameter Kaiser-Meyer-Olkin (KMO) dengan nilai $\mathrm{KMO}>0$,5. Selanjutnya, adanya korelasi antara variabel-variabel multivariat dapat teridentifikasi dengan parameter Bartlett's Test of Sphericity yang harus signifikansi dengan p-value lebih kecil dari 0,05 (p-value $<0,05)$. Besarnya korelasi antarvariabel multivariat dapat terlihat dari nilai Measure of Sampling Adequacy (MSA) dengan nilai MSA $>0,5$.

Analisis validitas konstrak model pengukuran dengan CFA pada Second Order CFA bertujuan untuk menguji kecocokan model yang diteorikan dengan data empirik. Kriteria utama kecocokan model dengan data lapangan jika terpenuhi minimal tiga syarat yaitu Chi-square (p-value) $>0,05$ dan Root Mean Square Error of Approximation (RMSEA) < 0,08 serta Comparative Goodness of Fit Indeks $(\mathrm{CFI}) \geq 0$,9. Jika model cocok dengan data lapangan, maka analisis dilakukan terhadap muatan faktor setiap indikator atau butir dalam model pengukuran. Namun, apabila sebaliknya, yaitu model tidak cocok dengan data lapangan analisis terhadap muatan faktor tidak dapat dilakukan. Langkah yang harus dilakukan adalah melakukan modifikasi model dengan mempertimbangkan indeks modifikasi pada output Lisrel. 
Penentuan validitas butir instrumen dengan second order CFA didasarkan pada pendapat Hair et al. (2010, p. 119) bahwa kriteria minimal nilai muatan faktor $(\lambda)$ yang dapat diterima adalah $\pm 0,3$ sampai 0,4 dan nilai-t $>1,96$ dengan taraf signifikansi $5 \%$. Dengan demikian, maka dalam penelitian ini digunakan kriteria nilai muatan faktor, $(\lambda) \geq 0,3$ dan nilai-t $>1,96$ untuk masingmasing butir instrumen. Selain itu, nilai-t muatan faktor tidak boleh negatif. Apabila kedua persyaratan muatan faktor sebuah butir tidak terpenuhi, maka butir dimaksud harus dihilangkan dari model serta dilakukan analisis ulang. Kemudian reliabilitas konstrak dianalisis dengan menggunakan formula Consruct Reliability dengan pertimbangan bahwa konstrak instrumen aktivitas guru cenderung mengarah pada multidimensi (Widhiarso \& Mardapi, 2010, p. 10). Kriteria minimal nilai reliabilitas konstrak (CR) menurut Ghozali \& Fuad (2012, p. 268) adalab $C R \geq 0,7$.

\section{Hasil Penelitian dan Pembahsan}

Data hasil penelitian pada tahap pendahuluan diperoleh melalui kegiatan pengumpulan data dan informasi lapangan serta studi pendahuluan. Kegiatan dimaksud meliputi: observasi awal di berbagai SMA untuk identifikasi masalah riil di lapangan, kajian pustaka, kajian peraturan, dan kajian hasil penelitian terdahulu. Tahapan ini bertujuan untuk menggali informasi aktual tentang implementasi pengembangan keprofesian berkelanjutan guru di sekolah.

Hasil studi pendahuluan dengan observasi awal di berbagai SMA menunjukkan, bahwa pengembangan keprofesian berkelanjutan guru dilaksanakan secara mandiri dan kelompok. Pada umumnya aktivitas pengembangan keprofesian guru meliputi, (1) membaca melalui media cetak dan elektronik; (2) mengembangkan perangkat pembeljaran dan penilaian; (3) pendidikan dan pelatihan fungsional dan kolektif, antara lain IHT, workshop, diklat, MGMP dan seminar; (4) membuat karya tulis berupa modul dan penelitian tindakan kelas (PTK); (5) refleksi proses pembelajaran yang dilakukan dengan peserta didik dan teman sejawat; dan (6) bekerjasama dengan teman sejawat dengan cara berbagi informasi dan bahan tentang konten terkini yang terkait dengan kurikulum, pembelajaran dan penilaian. $\mathrm{Na}$ mun tidak sedikit guru mengeluhkan minimnya kesempatan untuk mengikuti pelatihan yang difasilitasi oleh pemerintah.

Disamping itu, aktivitas pengembangan keprofesian tersebut dilaksanakan secara insidentil dan mandiri serta kurang terencana dengan baik, walaupun di sekolah telah memiliki unit kerja yang berfungsi untuk mengkordinasikan pengembangan keprofesian berkelanjutan bagi guru.

Berdasarkan kajian terhadap berbagai literatur tentang pengembangan keprofesian berkelanjutan guru, dirumuskan tujuh dimensi menjadi konstrak teoritik instrumen aktivitas pengembangan keprofesian berkelanjutan guru, yaitu: (1) aktivitas membaca, (2) pengembangan pembelajaran dan penilaian, (3) pendidikan dan pelatihan, (4) publikasi ilmiah, (5) publikasi karya inovatif, (6) reflektif, dan (7) aktivitas kolaboratif.

Hasil validasi ahli menunjukkan, bahwa para ahli memberikan penilaian yang relatif sama terkait konstrak aktivitas pengembangan keprofesian berkelanjutan guru. Secara umum indikator yang disusun dinilai sudah mewakili dimensi dari konstrak aktivitas pengembangan keprofesian berkelanjutan guru. Indikator-indikator yang disusun merupakan representasi dari penjabaran dimensi dari konstrak yang telah didefinisikan. Dengan demikian, konstruksi butir sudah sesuai dengan indikatornya.

Para ahli memberikan beberapa masukan terhadap butir-butir instrumen aktivitas pengembangan keprofesian yang disusun berdasarkan indikatornya. Ada beberapa butir instrumen yang saling tumpang tindih (overlap) serta mirip dalam satu dimensi sehingga butir tersebut harus direduksi. Hasil kajian para ahli terhadap perangkat instrumen menunjukkan bahwa secara umum instrumen tersebut cukup memadai jika dilihat dari penggunaan tata bahasa dan penulisannya. Bahasa yang digunakan dalam penyusunan perangkat in- 
strumen dinilai oleh para ahli cukup komunikatif dan mudah dimengerti. Selanjutnya, para pakar memberikan beberapa masukan untuk penyempurnaan instrumen, antara lain agar melengkapi indikator dan kriteria penskoran supaya lebih jelas, lebih operasional, mudah dipahami serta tidak membingungkan.

Uji keterbacaan instrumen melibatkan praktisi dari unsur-unsur yang terkait dengan calon pengguna model asesmen, yaitu guru, kepala sekolah, pengawas dan widyaiswara. Penilaian terhadap keterbacaan instrumen diarahkan pada aspek: (1) kejelasan petunjuk instrumen, (2) kejelasan indikator aktivitas membaca, (3) kejelasan indikator pengembangan pembelajaran dan penilaian, (4) kejelasan indikator pendidikan dan pelatihan, (5) kejelasan indikator publikasi ilmiah, (6) kejelasan indikator publikasi karya ilmiah, (7) kejelasan indikator aktivitas reflektif, (8) kejelasan indikator aktivitas kolaboratif, (9) penggunaan bahasa Indonesia baku, (10) rumusan pernyataan yang komunikatif, (11) penggunaan kalimat dan kata yang mudah dipahami, (12) tata tulis diarahkan pada penilaian bentuk huruf, ukuran huruf, dan format atau lay out instrumen. Adapun hasil penilaian dari dua tahap uji coba terhadap keterbacaan instrumen disajikan pada Tabel 1 .

Penilaian keterbacaan instrumen menggunakan skala 5 , yaitu skor minimal 1 dan skor maksimal 5. Tabel 1 menunjukkan rerata skor total pada uji coba ke-2 adalah 3,86. Apabila dikonsultasikan dengan pedoman konversi data kuantitatif ke kualitatif, berada pada rerata skor $>3,4-4,2$ dan termasuk dalam klasifikasi layak atau baik.
Hal ini memberi indikasi bahwa tingkat keterbacaan instrumen yang dikembangkan ini dapat diklasifikasikan layak atau baik.

\section{Uji Coba Tahap Awal}

Model hipotetik yang diuji secara empiris dalam penelitian ini adalah konsrak instrumen asesmen diri guru terhadap aktivitas pengembangan keprofesian berkelanjutan dengan tujuh dimensi, yaitu: (1) aktivitas membaca, (2) pengembangan pembelajaran dan penilaian, (3) pendidikan dan pelatihan, (4) publikasi ilmiah, (5) publikasi karya ilmiah, (6) aktivitas reflektif, (7) aktivitas kolaboratif. Model instrumen yang dikembangkan dinyatakan cocok dengan data lapangan apabila sudah terpenuhi dua kriteria dari tiga kriteria yang menjadi ukuran kecocokan yaitu Root Mean Square Error of Approximation (RMSEA) < 0,08; Chi-Square yang diperoleh dari pengujian memiliki probabilitas lebih besar dari 0,05 ( $\mathrm{p}>0,05)$; dan Comparative Goodness of Fit Indeks (CFI) $\geq 0,90$.

Hasil analisis faktor dengan program SPSS 17.0 menunjukkan bahwa nilai KMO sebesar 0,921 (KMO>0,50). Sementara itu, nilai Bartlett's Test of Sphericity menunjukkan signifikansi p-value lebih kecil dari 0,05 (p-value $<0,05)$. Hasil ini menunjukkan telah terpenuhinya kecukupan jumlah observasi (data) dan adanya korelasi yang signifikan antara variabel-variabel observasi aktivitas pengembangan keprofesian berkelanjutan guru. Dengan demikian, maka data hasil observasi telah memenuhi syarat untuk analisis faktor konfimatori.

Tabel 1. Rekapitulasi Hasil Uji Keterbacaan Instrumen Asesmen Diri pada Aktivitas PKB Guru SMA

\begin{tabular}{ccccccccccccccc}
\hline \multirow{2}{*}{ Tahap } & Jml. & \multicolumn{11}{c|}{ Rerata Skor } & \multicolumn{1}{c}{ Rerata } \\
& Resp. & 1 & 2 & 3 & 4 & 5 & 6 & 7 & 8 & 9 & 10 & 11 & 12 & Total \\
\hline 1 & 20 & 4,00 & 3,74 & 3,63 & 3,79 & 3,68 & 3,79 & 3,63 & 3,68 & 3,63 & 3,74 & 3,79 & 3,79 & 3,78 \\
2 & 40 & 4,03 & 3,82 & 3,82 & 3,87 & 3,87 & 3,87 & 3,79 & 3,74 & 3,85 & 3,74 & 3,95 & 3,82 & 3,86 \\
\hline
\end{tabular}


Nilai Measure of Sampling Adequacy (MSA) menujukkan besarnya korelasi antar variabel multivariat. Menurut Hair (2010, p 120), bahwa batas nilai yang dapat diterima MSA $>0,50$. Hasil analisis terhadap nilai MSA menunjukkan terdapat 14 dari 55 butir memiliki variansi MSA $<0,5$ sehingga 14 butir tersebut dieleminasi dan tidak disertakan pada tahapan analisa berikutnya. Selanjutnya, jika dilihat kedudukan butir untuk setiap faktornya setelah dilakukan rotasi nampak bahwa semua butir dapat menjelaskan kedudukan butir dalam faktornya.

Dimensionalitas alat ukur dapat dilihat dari parameter nilai eigen pada setiap faktor. Hasil analisis terhadap variabel aktivitas guru menunjukkan parameter nilai eigen sebesar 13,07 dan variansi 31,12\% dengan jumlah faktor maksimum yang terbentuk 7 faktor, yaitu membaca, mengembangkan pembelajaran dan penilaian, diklat, publikasi ilmiah, publikasi karya inovatif, refleksi, dan kolaborasi. Hal ini menunjukkan, bahwa variansi masing-masing variabel $>20 \%$ sehingga dapat disimpulkan bahwa masing-masing variabel asesmen aktivitas PKB guru berdimensi satu (unidimensi).

Namun demikian, uji kecocokan model secara keseluruhan menunjukkan bahwa konstrak model pengukuran memiliki kecocokan model yang kurang baik (model tidak fit) dengan data lapangan, karena nilai $\chi^{2}$ (p-value $)=0,00<0,05 ;$ CFI $\geq 0,98$ dan RMSEA $<0,047$. Selanjutnya, langkah untuk memperoleh model yang fit adalah melakukan modifikasi terhadap model. Ghozali \& Fuad (2012, p. 170) menyarankan dua tipe modifikasi yang dapat dilakukan untuk memperoleh fit model yang baik, yaitu: (1) dengan menambah path (jalur) dari faktor (subdimensi) ke indikator yang berdasarkan analisis rasional merupakan cerminan faktor tersebut; dan (2) dengan mengkorelasikan antara dua error indicator (butir) yang memiliki residual kovarians yang besar.

Modifikasi model yang dipilih adalah dengan mengkorelasikan antara dua error indicator yang memiliki residual covarians yang besar, yaitu: (1) butir A3-A5 dalam dimensi membaca, (2) butir A7-A8 dalam dimensi pengembangan pembelajaran dan penilaian, (3) butir A15-A16 dan A21-A22 pada dimensi publikasi karya ilmiah, (4) butir A28A29 pada dimensi aktivitas reflektif, dan (5) butir A32-A34 dan A33-A34 pada dimensi aktivitas kolaboratif. Alternatif ini ditempuh karena tipe modifikasi ini bersifat tidak mengubah konstrak sebagaimana yang telah dihipotesiskan. Selain itu, secara konseptual korelasi antara indikator-indikator atau butir tersebut didasari oleh suatu argumen yang kuat bahwa kedua indikator yang dikorelasikan tersebut mengungkap trait yang hampir sama.

Hasil modifikasi terhadap model menunjukkan bahwa secara keseluruhan model pengukuran memiliki kecocokan yang baik (model fit), karena nilai Chi-Square $=817,26$ p-value $=0,085>0,05 ;$ RMSEA $=0,018<$ 0,08 dan $\mathrm{CFI}=1,00>0,90$. Dengan demikian, maka model pengukuran aktivitas pengembangan keprofesian berkelanjutan guru telah memenuhi kriteria unidimensi, yaitu sebanyak 41 butir (A1 s.d A41) yang merefleksikan dimensi aktivitas. Adapun model pengukuran aktivitas pengembangan keprofesian berkelanjutan guru setelah revisi pada second order CFA disajikan pada Gambar 1.

Selain itu, estimasi signifikansi parameter muatan faktor dengan kriteria nilai-t $>$ 1,96 dimaksudkan untuk mengetahui kelayakan sebuah butir menjadi alat ukur. Hasil estimasi nilai-t muatan faktor $(\lambda)$ menunjukkan, bahwa semua butir aktivitas guru memiliki nilai-t $>1,96$ dengan nilai muatan faktor standar $(\lambda)>0,3$ (rentang nilai 0,57 s.d 0,93 ) serta tidak ada nilai negatif. Selanjutnya, semua dimensi yang dikembangkan juga memiliki koefisien jalur $(\gamma)>0,30$ (rentang nilai 0,44 s.d 0,68 ) dengan nilai$\mathrm{t}>1,96$. Dengan demikian, dapat disimpulkan bahwa ke-41 butir instrumen terkait dengan aktivitas guru memenuhi syarat dan layak menjadi alat ukur dimensi aktivitas pengembangan keprofesian berkelanjutan guru

Evaluasi terhadap reliabilitas model pengukuran dilakukan dengan menggunakan composite reliability measure (ukuran reliabilitas komposit) atau yang dikenal juga dengan construct reliability (reliabilitas konstrak) 


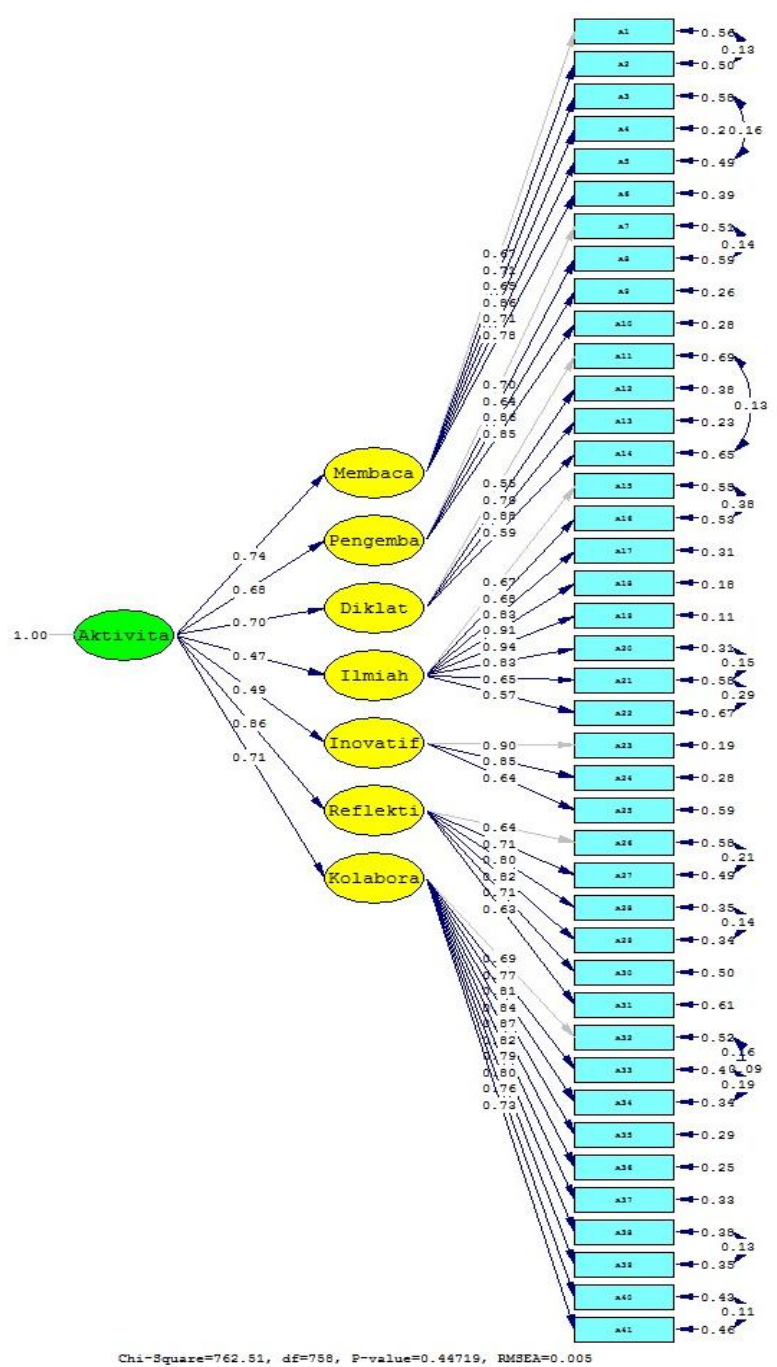

Gambar 1. Model Pengukuran

Asesmen Diri Guru pada Aktivitas

Pengembangan Keprofesian Berkelanjutan

Sebuah konstrak mempunyai reliabilitas yang baik jika nilainya lebih dari atau sama dengan 0,70 (Lance, Butts, \& Michels, 2006, p. 205). Berdasarkan hasil perhitungan reliabilitas konstrak, dapat disimpulkan bahwa reliabilitas konstrak model asesmen diri aktivitas pengembangan keprofesian berkelanjutan guru adalah baik $(\mathrm{CR}>0,70)$.

\section{Uji Coba Tahap Akhir}

Tahapan validasi empirik tahap awal telah menghasilkan konstrak asesmen diri guru pada pengembangan keprofesian berkelanjutan yang direfleksikan oleh tujuh dimensi, yaitu: (1) aktivitas membaca, (2) pengembangan pembelajaran dan penilaian,
(3) pendidikan dan pelatihan, (4) publikasi ilmiah, (5) publikasi karya ilmiah, (6) aktivitas reflektif, (7) aktivitas kolaboratif. Konstrak aktivitas guru pada pengembangan keprofesian berkelanjutan ini tercermin dalam 41 indikator. Tahapan selanjutnya adalah validasi empirik tahap akhir terhadap 41 butir pertanyaan tersebut pada 950 guru SMA.

Hasil analisis faktor dengan program SPSS 17.0 menunjukkan bahwa nilai KMO sebesar 0,941 (KMO>0,50), sedangkan nilai Bartlett's Test of Sphericity menunjukkan signifikansi p-value lebih kecil dari 0,05 (p-value $<0,05)$. Hasil ini menunjukkan telah terpenuhinya kecukupan jumlah observasi (data) dan adanya korelasi yang signifikan antara variabel-variabel observasi aktivitas guru. Dengan demikian, maka data hasil observasi terhadap aktivitas pengembangan keprofesian berkelanjutan guru telah memenuhi syarat analisis faktor konfimatori.

Hasil validasi empirik tahap akhir terhadap konstrak aktivitas pengembangan keprofesian berkelanjutan guru menunjukkan kecocokan keseluruhan model (overall model) yang baik (model fit), karena nilai ChiSquare $=762,51 \mathrm{p}$-value $=0,45>0,05$; RMSEA $=0,005<0,08$ dan $\mathrm{CFI}=1,00>$ 0,90 . Dengan demikian, maka model pengukuran aktivitas guru telah memenuhi kriteria unidimensi, yaitu sebanyak 41 butir (A1 s.d A41) yang merefleksikan dimensi aktivitas hanya mengukur hal yang sama, yaitu dimensi aktivitas pengembangan keprofesian berkelanjutan guru.

Selain itu, estimasi signifikansi parameter muatan faktor dengan kriteria nilai-t $>1,96$ dimaksudkan untuk mengetahui kelayakan sebuah butir menjadi alat ukur. Hasil estimasi nilai-t muatan faktor $(\lambda)$ menunjukkan, bahwa semua butir aktivitas guru memiliki nilai- $\mathrm{t}>1,96$ dengan nilai muatan faktor standar $(\lambda)>0,3$ (rentang nilai $0,55$ s.d 0,94$)$ serta tidak ada nilai negatif. Selanjutnya, semua dimensi yang dikembangkan juga memiliki koefisien jalur $(\gamma)>$ 0,30 (rentang nilai 0,47 s.d 0,86 ) dengan nilai-t $>1,96$. Dengan demikian, dapat disimpulkan bahwa ke-41 butir pertanyaan/ 
pernyataan yang terkait dengan aktivitas guru memenuhi syarat dan layak menjadi alat ukur aktivitas pengembangan keprofesian berkelanjutan guru.

Evaluasi terhadap reliabilitas model pengukuran dilakukan dengan menggunakan composite reliability measure (ukuran reliabilitas komposit) atau yang dikenal juga dengan construct reliability (reliabilitas konstrak) (Hair et al., 2010). Sebuah konstrak mempunyai reliabilitas yang baik jika nilainya lebih dari atau sama dengan 0.70 (Hair et al., 2010; Lance et al., 2006, p. 205). Berdasarkan ringkasan hasil perhitungan reliabilitas konstrak, dapat disimpulkan bahwa konstrak model asesmen diri pada aktivitas pengembangan keprofesian berkelanjutan guru adalah reliabel $(\mathrm{CR}>0,70)$.

Dari hasil analisis secara kuantitatif dan kualitatif, secara umum dapat dikatakan bahwa instrumen asesmen diri guru terhadap aktivitas pengembangan keprofesian berkelanjutan yang dikembangkan berdasarkan kajian teoretik dan telaah para pakar dan panelis serta uji coba secara empiris sudah sesuai dan dapat diaplikasikan. Jika dibandingkan antara konsep dan draf awal instrumen, terdapat beberapa perbaikan/revisi dan pengembangan sebagai hasil dari validasi oleh pakar dan panelis serta uji coba empiris kepada responden guru di lapangan baik tahap pertama dan tahap kedua. Pengembangan tersebut mencakup kesesuaian antara butir dengan indikator, indikator dengan dimensi pada konstrak latennya, serta penggunaan bahasa yang lebih komunikatif dan mudah dipahami.

Validitas mengukur sejauh mana suatu alat ukur mampu mengukur apa yang seharusnya diukur. Instrumen asesmen ini dikembangkan berdasarkan pada konteks lapangan dan kajian teoritik yang relevan. Hasil penilaian para pakar dan uji coba empiris menunjukkan bahwa instrumen tes ini memiliki validitas isi yang memadai sehingga layak sebagai alat ukur dan dapat digunakan sebagai instrumen pendukung dalam pembinaan dan pengembangan proesi dan karir guru.
Koefisien reliabilitas konstrak uji coba empiris pertama dan kedua lebih dari 0,7. Reliabilitas suatu alat ukur merupakan konsistensi atau keajegan alat ukur tersebut dalam mengukur apa yang diukur. Makin tinggi koefisien reliabilitas, makin dekat nilai sekor amatan dengan nilai komponen sekor yang sesungguhnya, sehingga nilai sekor amatan dapat digunakan sebagai pengganti komponen sekor yang sesungguhnya. Dengan demikian dapat dinyatakan bahwa hasil pengukuran dengan menggunakan instrumen ini menunjukkan aktivitas pengembangan keprofesian berkelanjutan guru SMA yang mendekati sesungguhnya.

\section{Simpulan}

Simpulan hasil penelitian ini adalah: (1) konstrak asesmen diri guru terhadap aktivitas pengembangan keprofesian berkelanjutan, dicerminkan oleh tujuh dimensi, yaitu: yaitu: (a) aktivitas membaca, (b) pengembangan pembelajaran dan penilaian, (c) pendidikan dan pelatihan, (d) publikasi ilmiah, (e) publikasi karya ilmiah, (f) aktivitas reflektif, dan (g) aktivitas kolaboratif. (2) hasil uji keterbacaan menunjukkan instrumen dalam kategori baik dan layak, rerata skor 3,86; (3) hasil analisis instrumen menunjukkan, bahwa seluruh instrumen valid (muatan faktor $>0,3$ dan nilai-t $>1,96$ ) dan koefisien reliabilitas konstrak $>0,7$ serta memenuhi syarat sebagai model yang fit (Chi-Square $=762,51 \mathrm{p}$-value $=0,45>0,05$; RMSEA $=0,005<0,08$ dan $\mathrm{CFI}=1,00$ $>0,90$ ); (4) instrumen asesmen diri yang dikembangkan memenuhi syarat validitas dan reliabilitas sehingga layak digunakan oleh guru sebagai asesmen diri terhadap aktivitas pengembangan keprofesian berkelanjutan.

Berdasarkan simpulan penelitian dapat disampaikan saran kepada peneliti lain di bidang asesmen pendidikan dapat menggunakan produk ini untuk menguji kecocokan model dengan responden guru-guru pada jenjang pendidikan dasar SD/MI dan SMP/MTs karena instrumen asesmen diri guru yang dihasilkan ini hanya divalidasi pada responden guru SMA. 


\section{Daftar Referensi}

Bakkenes, I., Vermunt, J. D., \& Wubbels, T. (2010). Teacher learning in the context of educational innovation: Learning activities and learning outcomes of experienced teachers. Learning and Instruction, 20(6), 533-548.

https://doi.org/10.1016/j.learninstruc .2009.09.001

Benson, P. (2007). Autonomy in language teaching and learning. Language Teaching, 40(1), 21. https://doi.org/10.1017/S026144480 6003958

Borg, W. R., \& Gall, M. D. (1983). Educational research: An introduction (4th ed.). New York: Longman Publishing.

Borko, H. (2004). Professional development and teacher learning: mapping the terrain. Educational Researcher, 33(8), 315.

https://doi.org/10.3102/0013189X03 3008003

Brew, A. (1999). Toward autonomous assessment: using self assessment and peer assessment. In S. Brown \& A. Glesner (Eds.), Assessment Matters in Higher Education. Open University Press.

Day, C., \& Sachs, J. (2004). International handbook on the continuing professional development of teachers. Berkshire: Open University Press.

de Vries, S., Jansen, E. P. W. A., \& van de Grift, W. J. C. M. (2013). Profiling teachers' continuing professional development and the relation with their beliefs about learning and teaching. Teaching and Teacher Education, 33, 78-89.

https://doi.org/10.1016/j.tate.2013.02 .006

Desimone, L. M. (2009). Improving impact studies of teachers' professional development: toward better conceptualizations and measures. Educational Researcher, 38(3), 181-199.
https://doi.org/10.3102/0013189X08 331140

Gaible, E., \& Burns, M. (2005). Using technology to train teachers: Appropriate uses of ICT for teacher professional development in developing countries. Washington, DC:

The International Bank for Reconstruction and Development/ World Bank.

Ghozali, I., \& Fuad. (2012). Structural equation modelling: teori konsep, dan aplikasi dengan Program LISREL 8.80 (3rd ed.). Semarang: Badan Penerbit Universitas Diponegoro.

Hair, J. F., Anderson, R. E., Tatham, R. L., \& Black, W. C. (2010). Multivariate data analysis (4th ed.). New Jersey: Prentice Hall.

Hoekstra, A., Brekelmans, M., Beijaard, D., \& Korthagen, F. (2009). Experienced teachers' informal learning: Learning activities and changes in behavior and cognition. Teaching and Teacher Education, 25(5), 663-673. https://doi.org/10.1016/j.tate.2008.12 .007

Kelchtermans, G. (2004). CPD for professional renewal: moving beyod knowledge for practice dalam. Open University Press McGraw-Hill Education. In C. Day \& J. Sachs (Eds.), International Handbook on the Continuing Professional Development of Teachers (pp. 217-237). Berkshire: Open University Press.

Kwakman, K. (2003). Factors affecting teachers' participation in professional learning activities. Teaching and Teacher Education, 19(2), 149-170. https://doi.org/10.1016/S0742051X(02)00101-4

Lance, C. E., Butts, M. M., \& Michels, L. C. (2006). The sources of four commonly reported cutoff criteria. Organizational Research Methods, 9(2), 202-220. https://doi.org/10.1177/10944281052 84919 
Menteri Pendidikan dan Kebudayaan

Republik Indonesia. (2010). Buku I:

Pedoman pengelolaan pengembangan

keprofesionalan berkelanjutan. Jakarta:

Kemdikbud.

Mullis, I. V. S., Martin, M. O., Foy, P., \& Arora, A. (2012). TIMSS 2011

international results in mathematics. Chestnut Hill, MA: TIMSS \& PIRLS

International Study Center, Boston College.

Plomp, T. J. (2007). Educational design research: an introduction. In $A n$ Introduction to Educational Research. Enschede: National Institute for Curriculum Development.

Rolheiser, C., \& Ross, J. A. (2005). Students Self-evaluation: what research says and what practice shows. Retrieved from http://moodle.manistee.org/pluginfile .php/59439/course/section/16807/S TUDENT SELF-EVALUATION WHAT RESEARCH SAYS AND WHAT PRACTICE SHOWS.pdf
Tynjälä, P. (2008). Perspectives into learning at the workplace. Educational Research Review, 3(2), 130-154. https://doi.org/10.1016/j.edurev.200 7.12.001

Widhiarso, W., \& Mardapi, D. (2010). Komparasi ketepatan estimasi koefisien reliabilitas teori skor murni klasik. Jumal Penelitian Dan Evaluasi Pendidikan, 14(1). Retrieved from http://journal.uny.ac.id/index.php/jp $\mathrm{ep} /$ article/view/1973

Wurinanda, I. (2015, December 30). Ratarata nilai UKG di bawah standar. Okezone News. Retrieved from https://news.okezone.com/read/2015 /12/30/65/1277618/rata-rata-nilaiukg-di-bawah-standar

Zubaidah, N. (2012, August 3). Hasil uji kompetensi guru memprihatinkan. Sindonews.com. Retrieved from https:// nasional.sindonews.com/read /662873/15/hasil-uji-kompetensiguru-memprihatinkan-1344004590 